\title{
Evaluating Water Lead Levels During the Flint Water Crisis
}

\author{
Kelsey J. Pieper, ${ }^{\dagger, \S \odot ~ R e b e k a h ~ M a r t i n, ~}{ }^{\dagger, \S}$ Min Tang, ${ }^{\dagger, \S \odot}$ LeeAnne Walters, ${ }^{\ddagger}$ Jeffrey Parks, ${ }^{\dagger}$ \\ Siddhartha Roy, ${ }^{\dagger}$ Christina Devine, ${ }^{\dagger}$ and Marc A. Edwards ${ }^{*}{ }^{\dagger}$ \\ ${ }^{\dagger}$ Civil and Environmental Engineering, Virginia Polytechnic Institute and State University, 418 Durham Hall, Blacksburg, Virginia \\ 24061, United States \\ ${ }^{\ddagger}$ Citizen Scientist, 212 Browning Avenue, Flint, Michigan 48507, United States
}

\section{Supporting Information}

\begin{abstract}
In April 2014, the drinking water source in Flint, Michigan was switched from Lake Huron water with phosphate inhibitors to Flint River water without corrosion inhibitors. The absence of corrosion control and use of a more corrosive source increased lead leaching from plumbing. Our city-wide citizen science water lead results contradicted official claims that there was no problem- our 90th percentile was $26.8 \mu \mathrm{g} / \mathrm{L}$, which was almost double the Lead and Copper Rule action level of $15 \mu \mathrm{g} / \mathrm{L}$. Back calculations of a LCR sampling pool with $50 \%$ lead pipes indicated an estimated 90th percentile lead value of $31.7 \mu \mathrm{g} / \mathrm{L}( \pm 4.3 \mu \mathrm{g} / \mathrm{L})$. Four subsequent sampling efforts were conducted to track reductions in water lead after the switch back to Lake

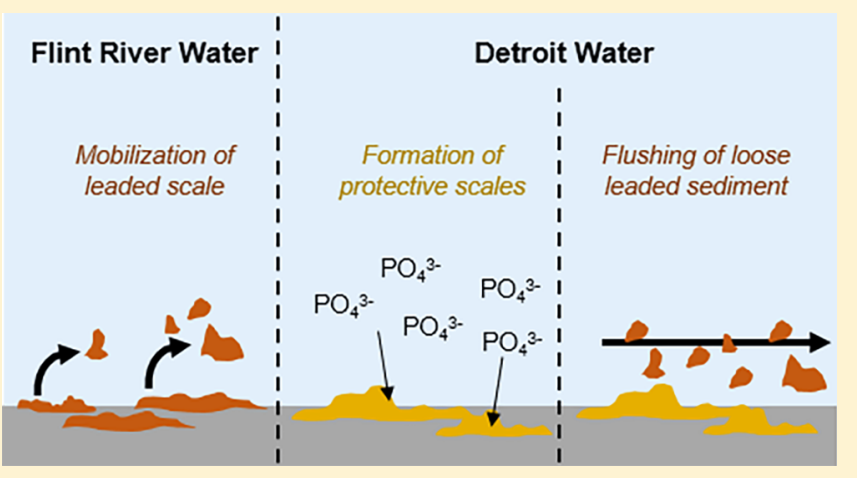
Huron water and enhanced corrosion control. The incidence of water lead varied by service line material. Between August 2015 and November 2016, median water lead reduced from 3.0 to $<1 \mu \mathrm{g} / \mathrm{L}$ for homes with copper service lines, 7.2-1.9 $\mu \mathrm{g} / \mathrm{L}$ with galvanized service lines, and 9.9-2.3 $\mu \mathrm{g} / \mathrm{L}$ with lead service lines. As of summer 2017, our 90th percentile of $7.9 \mu \mathrm{g} / \mathrm{L}$ no longer differed from official results, which indicated Flint's water lead levels were below the action level.
\end{abstract}

\section{INTRODUCTION}

It has long been understood that seemingly innocuous changes in water treatment and chemistry can impact water's aggressiveness toward lead pipes and lead-bearing plumbing components. One of the most high-profile examples was the 2001-2004 Washington, DC.lead crisis, in which high water lead levels (WLLs) were triggered by a change of secondary disinfection chemicals from free chlorine to chloramine to comply with new disinfection byproduct regulations. ${ }^{1-3}$ This disinfectant change elevated blood lead levels (BLLs) of hundreds of children above the previous CDC level of concern of $10 \mu \mathrm{g} / \mathrm{dL}$ and was also associated with increased incidence of adverse pregnancy outcomes. ${ }^{4,5}$ Similar lead in water events were documented in other U.S. cities after instituting treatment changes to comply with other drinking water regulations. ${ }^{6}$ Even modifications in water chemistry specifically aimed at reducing lead solubility have occasionally resulted in higher WLLs due to mobilization of particulate lead. ${ }^{7}$

To minimize water lead exposure, the U.S. Environmental Protection Agency (USEPA) Lead and Copper Rule (LCR) requires that water utilities monitor WLLs throughout the system at residents' taps and implement optimized corrosion control treatment. ${ }^{8}$ No more than $10 \%$ of first draw samples from high-risk homes may exceed the lead action level of 15 $\mu \mathrm{g} / \mathrm{L}$. Specifically, the LCR high-risk sampling approach requires utilities to collect at least $50 \%$ of samples from homes with lead service lines (LSLs) or from every home with a LSL if there are not enough to satisfy $50 \%$ of the sampling pool. This treatment technique rule monitors for system-wide contamination events and does not guarantee that a municipality's tap water is free of lead. ${ }^{9}$ Utilities implement corrosion control strategies to minimize lead leaching from premise plumbing components and LSLs by reducing lead solubility through $\mathrm{pH}$ adjustment and/or promoting formation of insoluble corrosion scales on pipe walls by dosing corrosion inhibitors. ${ }^{10-15}$ After implementing corrosion control for soluble lead, studies indicate that the majority of lead in water is often attributed to mobilization of particulate lead rather than soluble lead. ${ }^{7}$ The release of particulate lead is associated with the durability and adherence of lead-bearing corrosion scales and leaded solder. ${ }^{16}$

Water Crisis in Flint, Michigan: High Lead. For more than 45 years, the City of Flint purchased drinking water with optimized corrosion control from the Detroit Water and Sewer Department (DWSD). On April 25, 2014, DWSD drinking water service was discontinued and the city began distributing treated Flint River water. ${ }^{17}$ The Flint River was a more

Received: February 9, 2018

Revised: June 8, 2018

Accepted: June 22, 2018

Published: June 22, 2018 
corrosive and unstable water source, which did not have either optimized corrosion control or added orthophosphate corrosion inhibitors. ${ }^{18,19}$ In addition, to address a disinfection byproduct violation, the water operators switched from sulfatebased to chloride-based coagulants, increasing the chloride to sulfate mass ratio (CSMR) in the water from 0.45 to 2.04, which is above the critical trigger threshold of 0.5 that sometimes predicts accelerated galvanic lead corrosion problems. ${ }^{6,18}$ Short-term laboratory experiments confirmed that this increase in water corrosivity due to the absence of corrosion control and higher CSMR would be expected to dramatically increased lead and iron corrosion in Flint. ${ }^{20,21}$

LCR testing results collected in the home of LeeAnne Walters in Flint, termed "Resident Zero" for her instrumental role in revealing the contamination, indicated progressively increasing WLLs between February and May 2015. ${ }^{19}$ Intensive three-dimensional sampling at this home in April 2015 revealed WLLs of $217-13,200 \mu \mathrm{g} / \mathrm{L}$, attributable to the breakdown and detachment of lead-bearing iron corrosion scales from old lead and galvanized iron pipes. ${ }^{18}$ With the absence of corrosion control and prevalence of LSLs throughout Flint, these results suggested potential risk of a system-wide lead in water contamination event, as was also predicted in a memo by a USEPA Region V employee. ${ }^{19}$

The Virginia Tech Flint Water Study Team (www. FlintWaterStudy.org), citizen scientists of Flint, and supporting groups including American Civil Liberties Union of Michigan started an independent water lead investigation in August 2015. Preliminary results of this random sampling (in terms of known service line material per LCR high-risk sampling criteria) indicated a serious system-wide lead contamination event-the elevated WLLs were subsequently linked to an increased incidence of children with elevated BLLs. ${ }^{2,23}$ In late 2015, multiple interventions were implemented by the Michigan Department of Environmental Quality (MDEQ) and USEPA to reduce human exposure to elevated WLLs and restore effective corrosion control (Supporting Information (SI) Figure S1). Specifically, on October 16, 2015 (17 months after switching to Flint River water), Flint was reconnected to the original DWSD water source. ${ }^{17}$ On December 9, 2015, an additional $2.5-2.7 \mathrm{mg} / \mathrm{L}$ of orthophosphate inhibitor was added to the $1.2 \mathrm{mg} / \mathrm{L}$ as normal dose of orthophosphate added at DWSD. ${ }^{24}$ On May 1, 2016, residents were encouraged to participate in a high-flow flushing regimen (with no monetary impacts to their water bill) to help clean unstable leaded sediment and scale from the plumbing networks and hasten recovery of effective corrosion control. ${ }^{25}$

This manuscript presents the longitudinal data collected between August 2015 and August 2017, which define the WLLs during the Flint Water Crisis and subsequent water quality interventions. Specifically, the objectives of the study are to (1) evaluate system-wide lead contamination in August 2015 attributed to the switch to Flint River water and absence of corrosion control; (2) quantify the reduction in WLLs in 2016 and 2017 after MDEQ and USEPA interventions; and (3) examine variations in WLLs based on water quality parameters and service line characteristics.

\section{MATERIALS AND METHODS}

Water Lead Sampling. Each water lead kit prepared at Virginia Tech included sampling instructions and three sampling bottles. In addition, a demonstration video of the sampling protocol was made available. After a minimum of $6+$ hours of stagnation, residents were instructed to choose one drinking water tap (e.g., kitchen or bathroom faucet) to (1) collect $1 \mathrm{~L}$ of cold water at a normal flow (first draw sample); (2) flush the sample tap for $45 \mathrm{~s}$ and collect a $500 \mathrm{~mL}$ sample (1 min flush sample); and (3) flush the sample tap for an additional $2 \mathrm{~min}$ and collect a $125 \mathrm{~mL}$ sample (3 min flush sample). Along with water samples, residents provided sampling address, which was aggregated by the five primary zip codes for further analyses. After shipment to Virginia Tech, all samples were acidified with $2 \%$ nitric acid and digested for a minimum of $16 \mathrm{~h}$ before metals analysis via Inductively Coupled Plasma-Mass Spectrometry (ICP-MS) per Standard Method $3125 \mathrm{~B}^{26}$ For data quality assurance and quality control, blanks and spikes of known concentrations were measured every 10-15 samples. Residents were offered \$20 per sampling event after the first round of sampling in August 2015.

Participation in System-Wide Sampling. Five systemwide sampling campaigns were held in August 2015, March 2016, July 2016, November 2016, and August 2017 (SI Figure S1). The Flint citizen scientist team, led by Walters, advertised and distributed sampling kits throughout the city without knowledge of service line material. The team organized and coordinated distribution at local community sites, advertised participation among fellow residents, and delivered kits to residents with transportation barriers. Because of their effort, response rates were very high: $92 \%(n=277$ of 300$)$ of kits were returned in August 2015, 68\% ( $n=184$ of 269) in March 2016, $98 \%(n=176$ of 180$)$ in July 2016, $91 \%(n=164$ of $180)$ in November 2016, and 91\% $(n=164$ of 180) in August 2017. Participation in this testing was voluntary and residents were self-selected (i.e., high-risk homes with LSLs were not targeted as required by the LCR). However, virtually all homes in Flint were constructed before the 1986 ban on lead solder, which guaranteed a large pool of homes with at least leaded brass and lead solder.

Water samples from residences that were not on the Flint water system, as demonstrated by ICP-MS analysis (e.g., variation in baseline water quality) and sampling address, were removed from analysis. A total of 268 valid Flint samples were collected in August 2015. Of those 268 homes, a total of 186 participated in the next round in March 2016, and those who did not participate were dropped from later rounds. This approach led to 176 homes sampled in July 2016, 164 in November 2016, and 150 in August 2017 (SI Table S1). In total, 156 Flint residents participated in the first four sampling campaigns (August 2015 to November 2016) and 145 Flint residents participated in the annual sampling campaigns (August 2015, July 2016, and August 2017). Procedures were reviewed by the Virginia Tech Institutional Review Board (VT IRB) prior to sample collection, but this effort was deemed environmental monitoring rather than human subject research.

Retrospective Evaluation Using Suspected Service Line Material. In 2016, the University of Michigan-Flint developed a database of suspected service line materials in Flint homes based on city water department records. ${ }^{27}$ This service line database has been reported to accurately indicate the true service line material in $82 \%$ of the cases, with most error caused by records with "unknown" service line materials. ${ }^{28}$ To reconstruct a viable LCR sampling pool (i.e., $50 \%$ of samples from homes with LSLs), we paired our citizen science sampling results with their service line material from 
Table 1. Water Quality Results for August 2015 Sampling $(n=268)^{a}$

\begin{tabular}{|c|c|c|c|c|c|c|c|c|c|}
\hline \multirow[b]{2}{*}{ water quality statistics } & \multicolumn{3}{|c|}{$\mathrm{Pb}(\mu \mathrm{g} / \mathrm{L})$} & \multicolumn{3}{|c|}{$\mathrm{Fe}(\mathrm{mg} / \mathrm{L})$} & \multicolumn{3}{|c|}{$\mathrm{PO}_{4}{ }^{3-}$ as $\mathrm{P}(\mathrm{mg} / \mathrm{L})$} \\
\hline & FD & $1 \mathrm{MF}$ & $3 \mathrm{MF}$ & FD & $1 \mathrm{MF}$ & $3 \mathrm{MF}$ & FD & $1 \mathrm{MF}$ & $3 \mathrm{MF}$ \\
\hline above reporting level ${ }^{b}$ & $85 \%$ & $59 \%$ & $47 \%$ & $100 \%$ & $99 \%$ & $98 \%$ & $99 \%$ & $99 \%$ & $96 \%$ \\
\hline median & 3.5 & 1.4 & $<\mathrm{MRL}$ & 0.12 & 0.10 & 0.10 & 0.09 & 0.08 & 0.07 \\
\hline 90th percentile & 26.8 & 11.3 & 6.6 & 0.42 & 0.27 & 0.25 & 0.20 & 0.14 & 0.12 \\
\hline percent exceeding $^{c}$ & $17 \%$ & $6 \%$ & $4 \%$ & $14 \%$ & $8 \%$ & $6 \%$ & & & \\
\hline $\max$ & 158.0 & $1,051.0$ & 94.5 & 9.20 & 2.32 & 1.63 & 2.67 & 0.73 & 0.49 \\
\hline
\end{tabular}

${ }^{a} \mathrm{FD}=$ first draw; $1 \mathrm{MF}=1 \mathrm{~min}$ flush; $3 \mathrm{MF}=3 \mathrm{~min}$ flush. ${ }^{b}$ Minimum Reporting Level $(\mathrm{MRL}): \mathrm{Lead}(\mathrm{Pb})=1 \mu \mathrm{g} / \mathrm{L} ;$ iron $(\mathrm{Fe})=0.01 \mathrm{mg} / \mathrm{L}$; phosphate $\left(\mathrm{PO}_{4}{ }^{3-}\right)=0.03 \mathrm{mg} / \mathrm{L}$ as $\mathrm{PO}_{4}{ }^{3-}-\mathrm{P} .{ }^{c} \mathrm{~Pb}$ : USEPA action level of $15 \mu \mathrm{g} / \mathrm{L}$; Fe: USEPA secondary maximum contaminant level of $0.3 \mathrm{mg} /$ $\mathrm{L} ; \mathrm{PO}_{4}{ }^{3-}$ : there is no USEPA drinking water threshold

the University of Michigan-Flint database for two samplings campaigns (August 2015 and August 2017). One Virginia Tech sampled residence was not within the extent of the University of Michigan-Flint database and was removed from the analysis. For a viable 2015 LCR sampling event during the crisis using a pool of $50 \%$ homes with LSLs, first draw WLLs from the 32 homes sampled by Virginia Tech identified as having LSLs were combined with 32 randomly selected homes with copper or galvanized service line materials. Ten sampling pools were generated using the identified LSLs and randomly selected non-LSL homes and the average 90th percentile and standard deviation are reported. This approach was also used to reconstruct a viable August 2017 LCR sampling event using the 22 Virginia Tech sampled homes with LSLs. To examine the impact of LSLs a sampling pool on the resulting 90th percentile, ten sampling pools of 30 homes from the August 2015 campaign were constructed with varying percentages of LSLs. The 90th percentile and standard deviation are reported.

Statistical Analysis. Statistical analyses on the citizen science sampling data (not reconstructed sampling pools) were conducted in $\mathrm{R}$ version 3.4.3 assuming an alpha of 0.05 as an indication of significance. Spearman's rho was used to evaluate correlations between lead and other metals and phosphate in water. The Kruskal-Wallis test was performed to examine relationships between WLLs and service line material. A test of proportions was used to compare WLLs among zip codes. The minimum reporting level (MRL) was $1 \mu \mathrm{g} / \mathrm{L}$ for lead, 0.01 $\mathrm{mg} / \mathrm{L}$ for iron, and $0.03 \mathrm{mg} / \mathrm{L}$ as $\mathrm{PO}_{4}{ }^{3-}-\mathrm{P}$, and all measurements below the MRL were set to half the MRL.

\section{RESULTS DURING HEIGHT OF CRISIS}

System-Wide Lead in Water Contamination Event. Although Flint reported compliance with the LCR in 2014 and $2015,{ }^{19,29-31}$ water lead results from our survey of 268 homes in the first round of citizen led sampling (August 2015) indicated that there was a system-wide lead in water contamination problem. Specifically, the 90th percentile WLL from this survey was $26.8 \mu \mathrm{g} / \mathrm{L}$, which was nearly two times the lead action level of $15 \mu \mathrm{g} / \mathrm{L}$ (Table 1 ). The median WLL was $3.5 \mu \mathrm{g} / \mathrm{L}$, and $85 \%$ of samples contained lead above the minimum reporting level $(\geq 1 \mu \mathrm{g} / \mathrm{L})$. The magnitude of WLLs reported was thought to be the lower bound of what was possible in a legitimate LCR sampling event because our random sampling pool was unlikely to have achieved the minimum $50 \%$ of LSLs required by the LCR. The incidence of elevated WLLs was evident throughout the city. The 90th percentile value for lead was $16.5-33.2 \mu \mathrm{g} / \mathrm{L}$ in the five primary zip codes represented in this study (48503-48507; $n$ = 44-68; SI Table S2). However, there were no differences in median first draw WLLs in the different zip codes (Kruskal-
Wallis, $p=0.36$ ), which ranged from 2.8 to $5.1 \mu \mathrm{g} / \mathrm{L}$. There was also no difference based on zip code for homes with detectable lead (80-91\%; Test of Proportions, $p=0.46$ ) as well as homes exceeding the action level $(13-21 \% ; p=0.84)$.

Flushing the tap water for several minutes reduced WLLs. The 90th percentile for 1 min flush samples was $11.3 \mu \mathrm{g} / \mathrm{L}$, but $59 \%$ of samples still had reportable lead. This trend continued with additional flushing, as the 90th percentile for $3 \mathrm{~min}$ flush samples was $6.6 \mu \mathrm{g} / \mathrm{L}$ and $47 \%$ contained reportable lead. Median WLLs after 1 min of flushing ranged from <1.0-2.5 $\mu \mathrm{g} / \mathrm{L}$ and $<1.0-1.2 \mu \mathrm{g} / \mathrm{L}$ after 3 min of flushing (SI Table S2). More pronounced was the difference in percentage of homes with reportable lead ( $p=0.03$ and $p=0.008$, respectively). For example, reportable lead was observed after 1 and $3 \mathrm{~min}$ of flushing in $72 \%$ and $63 \%$ of homes in zip code $48503(n=68)$ compared to only $43 \%$ and $30 \%$ of homes in zip code 48506 ( $n$ $=44$ ). Overall, flushing reduced WLLs in most Flint homes and the effectiveness was a function of zip code, but there were still heath concerns about sustained low-to-moderate WLLs and spikes in water lead above the action level. ${ }^{32}$

Mobilization of Unstable Leaded Scales. During the time on the Flint River water supply, measurements in a building located less than $400 \mathrm{~m}(1312 \mathrm{ft}$.) from the Flint Water Treatment Plant had undetectable phosphate $(<0.03$ $\mathrm{mg} / \mathrm{L}$ as $\left.\mathrm{PO}_{4}{ }^{3-}-\mathrm{P}\right)$, confirming the absence of detectable levels of corrosion control inhibitors. However, the deterioration of leaded corrosion scale layers that accumulated over decades, at the home of Resident Zero, leached legacy phosphate to the water at relatively high levels $(0.4-9.9 \mathrm{mg} / \mathrm{L}) .{ }^{18}$ Sloughing of legacy phosphate was also evident in the system-wide samples collected in August 2015. Although detectable orthophosphate had not been added to the distributed water for more than 15 months, $99 \%$ of first draw samples still contained detectable phosphate (Table 1). The median first draw phosphate concentration was $0.09 \mathrm{mg} / \mathrm{L}$ as $\mathrm{PO}_{4}{ }^{3-}-\mathrm{P}$, which only reduced slightly with flushing, as median phosphate levels in the $1 \mathrm{~min}$ and $3 \mathrm{~min}$ flush samples were 0.08 and $0.07 \mathrm{mg} / \mathrm{L}$ as $\mathrm{PO}_{4}{ }^{3-}-\mathrm{P}$. Even after 3 min of flushing, $96 \%$ of water samples contained detectable phosphate in water.

Consistent with the theory that the pre-existing plumbing system scales were destabilized, WLLs in the first draw samples were correlated $(p<0.05)$ with iron $(\rho=0.40)$ and phosphate $(\rho=0.42)$. These correlations decreased with flushing of fresh water from mains through home plumbing, as lead was only weakly correlated with iron $(\rho=0.30)$ and phosphate $(\rho=$ 0.34) after $1 \mathrm{~min}$ of flushing and was not correlated after $3 \mathrm{~min}$ of flushing. We speculate that this reduction in WLLs was associated with a progressive cleaning of the plumbing network attributed to removal of unstable and detached leaded scales, as was observed in the home of Resident Zero. ${ }^{18}$ However, 
$13 \%$ of 1 min flush samples $(n=35)$ and $5 \%$ of 3 min flush samples $(n=13)$ contained higher water lead compared to the initial first draws (increases of $1-1044 \mu \mathrm{g} / \mathrm{L}$ ), which was attributed to the continued mobilization of leaded rust layers from service lines or other sources. In these samples, lead was correlated with iron in $1 \mathrm{~min}$ flush samples $(\rho=0.40)$ but not phosphate $(\rho=0.31, p=0.07)$, and lead was not correlated with iron or phosphate in the $3 \mathrm{~min}$ flush samples. However, iron and phosphate were correlated in $3 \mathrm{~min}$ flush samples $(\rho$ $=0.55, p=0.049$ ), suggesting continued presence of sloughing destabilized corrosion scale in flushed water, and highlighting the heterogeneous nature of corrosion scales dependent on the location of leaded materials within the water systems.

The switch to ferric chloride coagulant increased the CSMR, as water supplied by DWSD had a CSMR of 0.45 while the mean CSMR values for the 3 min flush samples was 3.48. CSMR values above 0.5 have been known to cause serious lead in water problems for residences with galvanic connections such as lead solder, partial LSLs, and copper deposition. 6,33,34 During the August 2015 sampling during the time with high CSMR water, 46 samples collected from 36 homes had detectable tin $(>1 \mu \mathrm{g} / \mathrm{L})$ in water. Four samples contained detectable tin without detectable cadmium $(>1 \mu \mathrm{g} / \mathrm{L})$, suggesting the detachment of lead-tin solder particles. The other 42 samples had 1:1 ratio of detectable tin to detectable cadmium (standard deviation \pm 0.19 ), which was consistent with the findings at Ground Zero impacted by galvanized iron pipe. ${ }^{18}$ This tin-cadmium ratio was observed in water samples collected in January and April 2015 collected from the from Resident Zero, and also measured in the original surface coating of the galvanized iron pipe excavated from that home.

Variation in WLLs Based on Service Line Material. Based on the University of Michigan-Flint database, half (52\%) of the homes sampled in August 2015 had copper service lines $(n=140), 16 \%$ had galvanized iron service lines $(n=44), 12 \%$ had partial or full LSLs $(n=32)$, and $19 \%$ had an unknown service line material $(n=51)$. This confirmed our expectation that the nontargeted citizen science sampling had underrepresented LSLs compared to the minimum 50\% requirement of the LCR. Among the five zip codes represented in this study, there were differences in the types of service line materials present, which is consistent with other Flint service line surveys. $^{28}$ For example, $28 \%$ of service lines were copper in 48503 compared to $73 \%$ in 48506 , which was believed to influence the presence of water lead at the tap, creating differences in water lead at the tap in these two zip codes as noted earlier.

As might be predicted, the median first draw WLLs were significantly lower $(p<0.05)$ in homes with copper service lines $(2.4 \mu \mathrm{g} / \mathrm{L})$ compared to lead $(7.6 \mu \mathrm{g} / \mathrm{L})$, galvanized $(5.8$ $\mu \mathrm{g} / \mathrm{L})$, and unknown service lines $(6.3 \mu \mathrm{g} / \mathrm{L}$; Figure 1$)$. This pattern was maintained during flushing, as homes with copper service lines had WLLs $<1 \mu \mathrm{g} / \mathrm{L}$ compared to measurable concentrations reported in homes with lead, galvanized iron, and unknown service lines. Thus, the WLLs varied based on service line material as expected. ${ }^{35}$

Reconstructing a Viable LCR High-Risk Sampling Pool. To back-calculate and construct a viable LCR sampling pool with $50 \%$ of homes with LSLs, results from all 32 homes with LSLs were selected along with 32 randomly selected homes with galvanized iron or copper service lines. The average 90th percentile lead value across 10 simulations of a viable LCR sampling pool was $31.7 \mu \mathrm{g} / \mathrm{L}( \pm 4.3 \mu \mathrm{g} / \mathrm{L})$, with

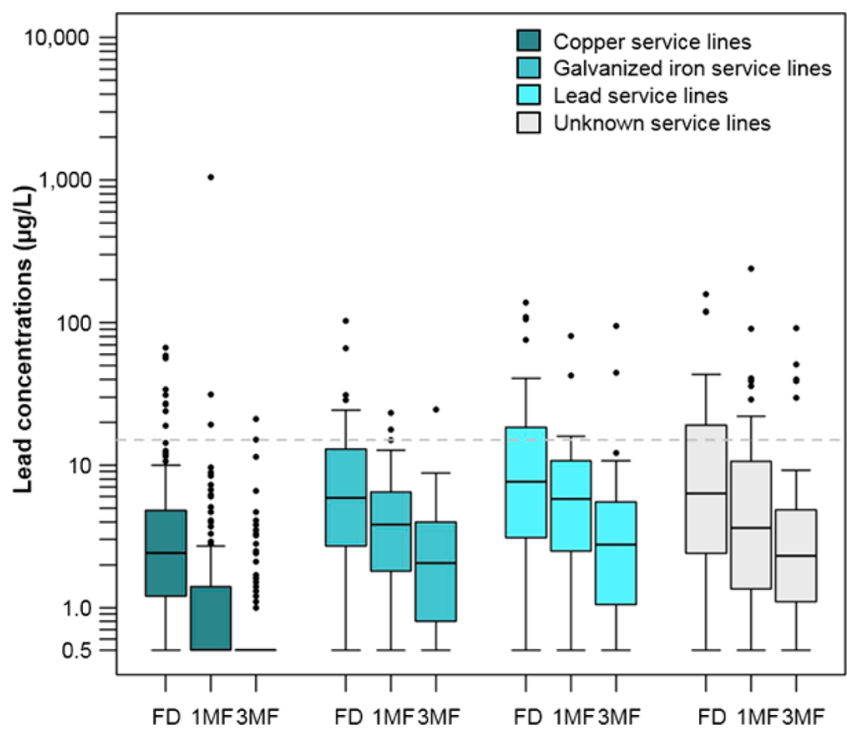

Figure 1. Water lead levels in August 2015 collected through a citizen science sampling campaign based on service line material. Action level $(15 \mu \mathrm{g} / \mathrm{L})$ denoted by gray line. Water lead levels $<1 \mu \mathrm{g} / \mathrm{L}$ were set to $0.5 \mu \mathrm{g} / \mathrm{L} . \mathrm{FD}=$ first draw; $1 \mathrm{MF}=1 \mathrm{~min}$ flush sample; $3 \mathrm{MF}=3 \mathrm{~min}$ flush sample.

median WLL of $4.3( \pm 0.4) \mu \mathrm{g} / \mathrm{L}$. Considering random pools of 64 homes with exclusively reported copper service lines (nonleaded pipe), the average 90th percentile lead value was $10.7 \mu \mathrm{g} / \mathrm{L}( \pm 3.5 \mu \mathrm{g} / \mathrm{L})$ and the median WLL was $2.4( \pm 0.3)$ $\mu \mathrm{g} / \mathrm{L}$. The "official" 90th percentile lead level reported by the City of Flint was $6 \mu \mathrm{g} / \mathrm{L}$ in 2014 and $11 \mu \mathrm{g} / \mathrm{L}$ in $2015,{ }^{17}$ which based on these results suggests only a small percentage of homes with LSLs was sampled, leading to under-estimation of lead at the tap compared to legal requirements. ${ }^{17,19}$ It was later acknowledged that the Flint sampling pool did not target homes with LSLs as required by law, and use of the University of Michigan-Flint database indicates that only nine of the homes sampled in the "official" 2014 pool (13\%; $n=96$ of 100; four homes could not be located) and only 7 homes sampled in $2015(10 \% ; n=69)$ had LSLs. ${ }^{17,27}$

\section{STATE AND FEDERAL INTERVENTIONS IMPACT OF WATER LEAD}

To evaluate the effectiveness of MDEQ and USEPA interventions on WLLs, after the August 2015 sampling event revealed the widespread water lead contamination problem, three follow-up sampling efforts were conducted in March, July, and November 2016. Overall, data from the same 156 Flint homes who participated in all four sampling efforts (including August 2015) were used for these analyses (Table 2).

Reconnection to DWSD and Supplementing Orthophosphate Inhibitors to Reduce WLLs. Water purchased from DWSD had an average orthophosphate dose of $1.2 \mathrm{mg} / \mathrm{L}$ as $\mathrm{PO}_{4}{ }^{3-}-\mathrm{P}$ and additional orthophosphate inhibitors were introduced at the Flint water plant $\left(2.5-2.7 \mathrm{mg} / \mathrm{L}\right.$ as $\mathrm{PO}_{4}{ }^{3-}$ $\mathrm{P})$, resulting in a targeted orthophosphate dose of $3.7-3.9 \mathrm{mg} /$ $\mathrm{L}$ as $\mathrm{PO}_{4}{ }^{3-}-\mathrm{P}$ in the distributed water. ${ }^{24}$ During the March 2016 sampling campaign, median phosphate levels were 3.45 $\mathrm{mg} / \mathrm{L}$ as $\mathrm{PO}_{4}{ }^{3-}-\mathrm{P}$ in the first draw, $3.58 \mathrm{mg} / \mathrm{L}$ as $\mathrm{P}$ in the $1 \mathrm{~min}$ flush, and $3.62 \mathrm{mg} / \mathrm{L}$ as $\mathrm{PO}_{4}{ }^{3-}-\mathrm{P}$ in the $3 \mathrm{~min}$ flush (Table 2). As expected, median phosphate levels in the $3 \mathrm{~min}$ flush 
Table 2. Water Quality Data at 156 Homes That Participated in the Four Sampling Efforts between August 2015 and November $2016^{a}$

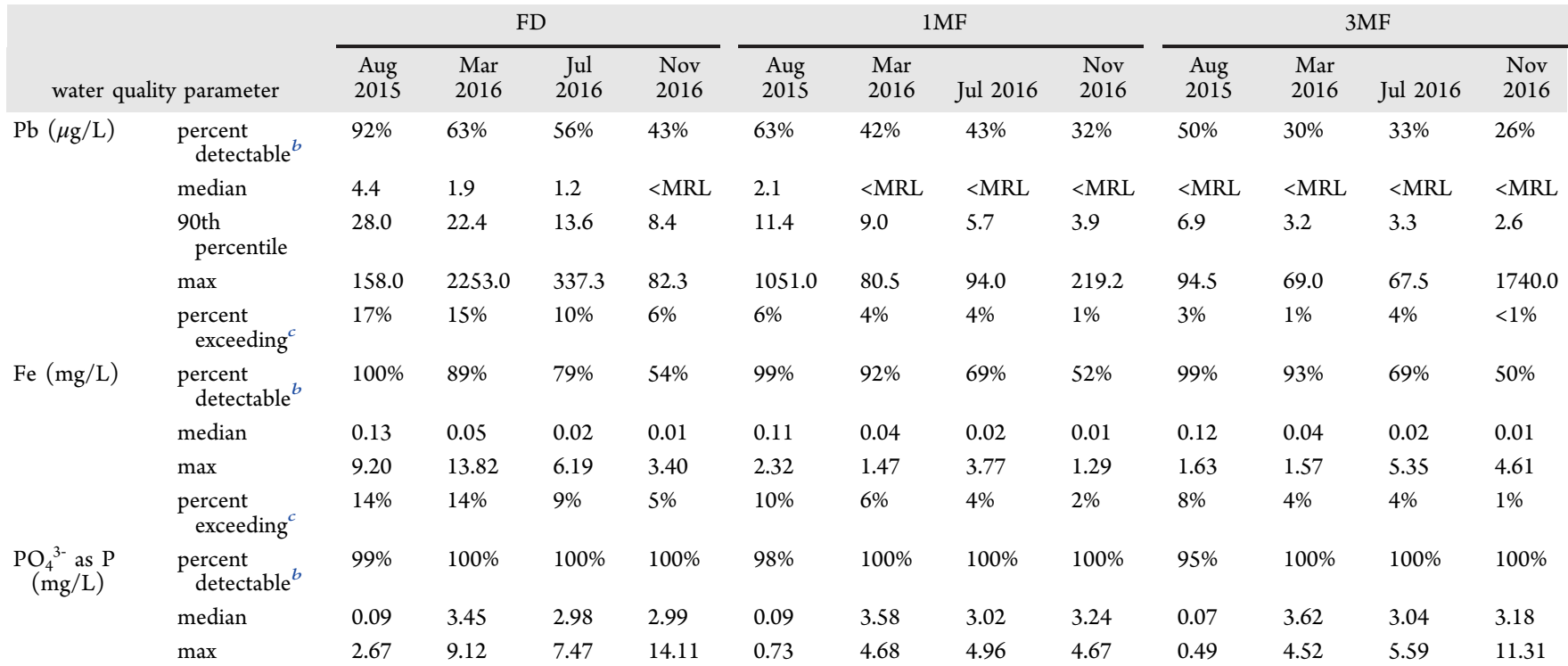

${ }^{a} \mathrm{MRL}=$ minimum reporting level; $\mathrm{FD}=$ first draw; $1 \mathrm{MF}=1 \mathrm{~min}$ flush; $3 \mathrm{MF}=3 \mathrm{~min}$ flush. ${ }^{b}$ Minimum reporting level: Lead $(\mathrm{Pb})=1 \mu \mathrm{g} / \mathrm{L} ; \mathrm{Iron}$ $(\mathrm{Fe})=0.01 \mathrm{mg} / \mathrm{L}$; phosphate $\left(\mathrm{PO}_{4}{ }^{3-}\right)=0.03 \mathrm{mg} / \mathrm{L}$ as $\mathrm{PO}_{4}{ }^{3-}-\mathrm{P} .{ }^{c} \mathrm{~Pb}$ : USEPA action level of $15 \mu \mathrm{g} / \mathrm{L}$; Fe: USEPA secondary maximum contaminant level of $0.3 \mathrm{mg} / \mathrm{L}$; $\mathrm{PO}_{4}{ }^{3-}$ : there is no USEPA drinking water threshold.

samples were significantly higher in March 2016 compared to August 2015 (3.62 vs $0.07 \mathrm{mg} / \mathrm{L} ; p<0.05$ ), which was attributed to the enhanced phosphate dosing. In addition, WLLs were lower, as median WLLs in the first draw reduced from 4.4 to $1.9 \mu \mathrm{g} / \mathrm{L}$ and percentage of first draw with reportable lead reduced from $92 \%$ to $63 \%$. However, the 90th percentile WLL in the March 2016 sampling round was still $22.4 \mu \mathrm{g} / \mathrm{L}$, almost 1.5 times the action level despite sampling less than the required percentage of homes with LSLs.

Consistent with findings observed during the August 2015 campaign, short-term flushing reduced WLLs at the tap in March 2016. Only 4\% and 1\% of homes had WLLs above the action level after $1 \mathrm{~min}$ and $3 \mathrm{~min}$ flushing, and $42 \%$ and $30 \%$ of homes had reportable lead. However, several homes were still experiencing issues with sporadic spikes in lead, with maximum WLLs of $2253 \mu \mathrm{g} / \mathrm{L}$ in first draw, $81 \mu \mathrm{g} / \mathrm{L}$ in $1 \mathrm{~min}$ flush, and $69 \mu \mathrm{g} / \mathrm{L}$ in $3 \mathrm{~min}$ flush. Lead in these three samples was most likely in the particulate form, as evidence by the higher phosphate $\left(4.3-9.1 \mathrm{mg} / \mathrm{L}\right.$ as $\left.\mathrm{PO}_{4}{ }^{3-}-\mathrm{P}\right)$ and iron concentrations $(1.25-13.8 \mathrm{mg} / \mathrm{L})$. Thus, we speculate that the unstable lead corrosion scales were continuing to be removed with water use, resulting in lower WLLs at the tap but sporadic spikes in high lead.

Flushing Destabilized Leaded Scales and Sediments within Plumbing Network. Based on our results from March 2016 and similar findings from MDEQ and USEPA sampling campaigns, it was suggested that Flint residents needed to flush their plumbing networks to help remove leaded sediment and distribute orthophosphate to the tap. Each day between May 1-15, Flint residents were encouraged to run the bathtub faucet for $5 \mathrm{~min}$ at the highest flow rate. ${ }^{25}$ During the July 2016 sampling campaign, median phosphate levels were consistent across the three samples at $3.0 \mathrm{mg} / \mathrm{L}$ as $\mathrm{PO}_{4}{ }^{3-}$-P (Table 2). WLLs were lower when sampled July compared to March, as median first draw WLLs reduced from 1.9 to $1.2 \mu \mathrm{g} / \mathrm{L}$ and percentage of first draw with reportable lead decreased from $63 \%$ to $56 \%$. In addition, the 90th percentile WLL measured in July 2016 was $13.6 \mu \mathrm{g} / \mathrm{L}$ in this nontargeted sampling approach. For the 15 homes with WLLs above the action level, lead was correlated with iron $(\rho=0.52)$ and phosphate $(\rho=0.63)$, again suggesting mobilization of leaded rust layers. Even after 1 and 3 min of flushing, 4\% and $4 \%$ of homes still had WLLs above the action level.

An additional sampling campaign was conducted in November 2016 to evaluate long-term improvements. WLLs again reduced slightly, as the median WLL was $<1 \mu \mathrm{g} / \mathrm{L}$ and percentage of first draw with reportable lead decreased to $43 \%$. The 90th percentile WLL observed during the November 2016 sampling effort was $8.4 \mu \mathrm{g} / \mathrm{L}$. As in the other sampling campaigns, mobilization of lead (presumably particulate) was still a problem for several residences, as the maximum WLLs were $82 \mu \mathrm{g} / \mathrm{L}$ in first draw, $219 \mu \mathrm{g} / \mathrm{L}$ in $1 \mathrm{~min}$ flush, and 1740 $\mu \mathrm{g} / \mathrm{L}$ in $3 \mathrm{~min}$ flush. However, steady reduction in WLLs continued to be observed with flushing, as only $1 \%$ and $0.6 \%$ of homes had lead above the action level after $1-$ and $3 \mathrm{~min}$ of flushing. Overall, findings from this year long effort were consistent with prior work, Goovaerts (2016) observed a consistently high percentage of homes with WLLs above the action level starting in late February 2016, which began decreasing in May 2016. ${ }^{28}$

Variation in WLLs during Interventions Based on Service Line Material. During the four sampling campaigns, there were inconsistencies in WLLs at a given residence, as some residents had higher first draw WLLs (increase $\geq 5 \mu \mathrm{g} / \mathrm{L}$ ) than in earlier sampling rounds. Specifically, $15 \%$ of residents ( $n=24)$ had higher first draw WLLs in March 2016 than August $2015 ; 11 \%(n=17)$ in July than March 2016 ; and $8 \%$ $(n=12)$ in November than July 2016. These findings suggest that homes with low WLLs in past sampling efforts were still at risk for water lead contamination in the future, as would be expected given the semirandom nature of particulate lead release.

Steady improvements in water lead were observed between August 2015 and November 2016 in homes with a reported 
copper service line $(n=80$; Figure 2$)$. After reconnection to DWSD with enhanced corrosion control, median WLLs
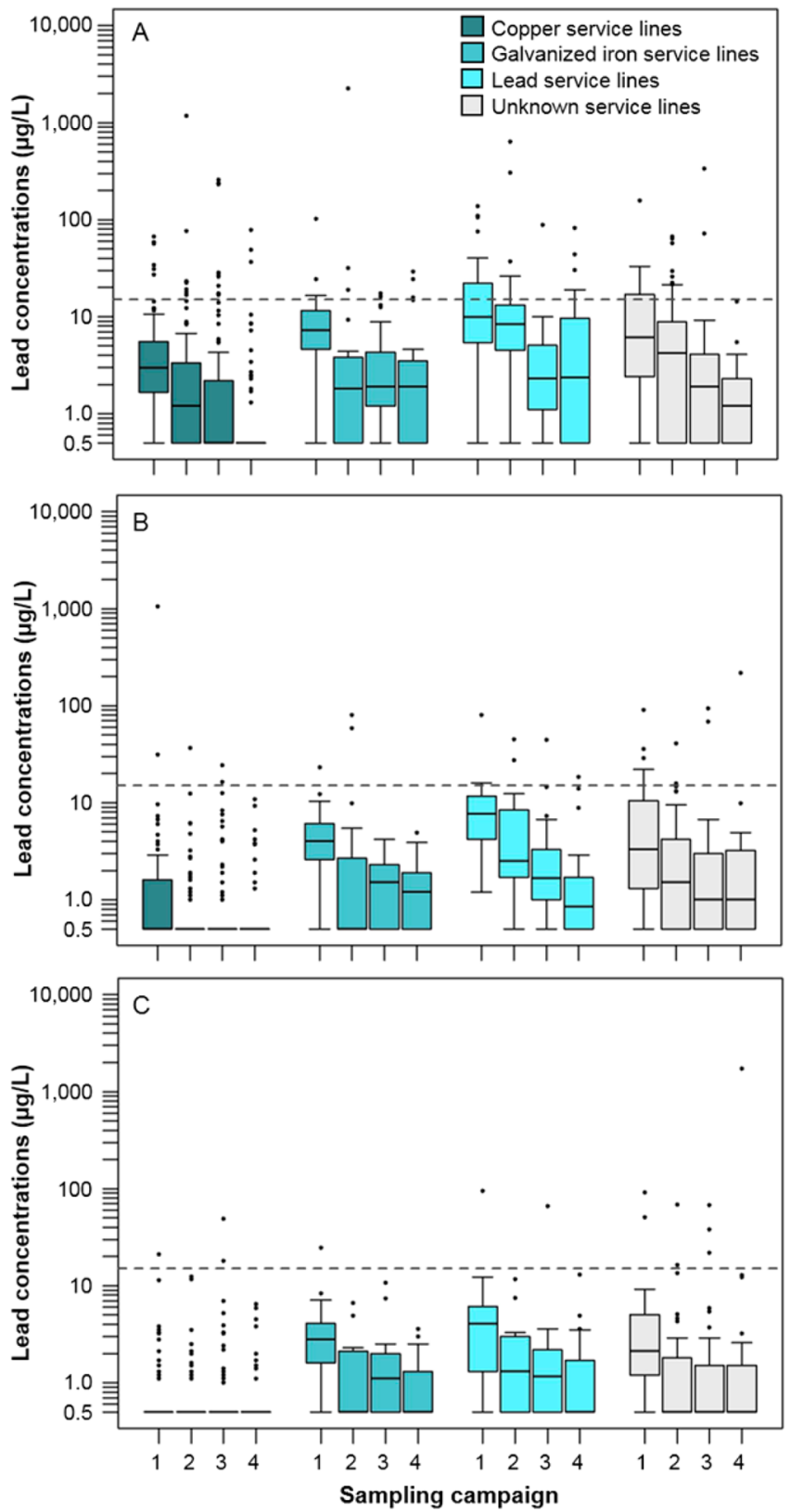

Figure 2. Water lead levels observed throughout the four sampling campaigns based by service line material for (A) first draw samples, (B) $1 \mathrm{~min}$ flush samples and (C) $3 \mathrm{~min}$ flush samples. Action level (15 $\mu \mathrm{g} / \mathrm{L})$ denoted by gray line. Water lead levels $<1 \mu \mathrm{g} / \mathrm{L}$ were set to 0.5 $\mu \mathrm{g} / \mathrm{L}$. Sample campaigns: 1 = August 2015, $2=$ March 2016; 3 = July 2016; 4 = November 2016 .

reduced from 3.0 to $1.2 \mu \mathrm{g} / \mathrm{L}$ and the percentage of homes with reportable lead decreased from $88 \%$ to $51 \%$. In both July and November 2016, the median WLL was $<1 \mu \mathrm{g} / \mathrm{L}$ and the population with reportable lead decreased to $40 \%$ and $24 \%$. Despite these improvements, the 90th percentile WLLs increased-from 12.0 to $17.2 \mu \mathrm{g} / \mathrm{L}-$ through July 2016 but decreased to $4.5 \mu \mathrm{g} / \mathrm{L}$ in November 2016. The high water lead in these homes is attributed to premise plumbing corrosion of soldered joints and brass fittings.
Improvements in water lead in homes with galvanized iron service lines $(n=21)$ were observed between August 2015 and November 2016. By March 2016, median WLLs from these homes decreased from 7.2 to $1.8 \mu \mathrm{g} / \mathrm{L}$ and the population with reportable lead decreased to $95 \%$ and $67 \%$, which remained relatively constant between March and November 2016. In homes with LSLs $(n=22)$, there was no decrease in median first draw WLLs in March 2016 (9.9 vs $8.3 \mu \mathrm{g} / \mathrm{L} ; p=0.51$ ), but median WLLs decreased to $2.3 \mu \mathrm{g} / \mathrm{L}$ in July and November 2016. However, throughout this campaign between 73 and $95 \%$ of these homes had reportable lead. Similar sustained low WLLs in homes with galvanized iron and lead service lines have also been reported in Canada, ${ }^{35}$ indicating that these service line materials may continually leach low levels of lead to water even if optimal corrosion control is in place.

Direct Comparison without Seasonal Impact in Summer 2015, 2016, and 2017. To more definitively evaluate the long-term effectiveness of the interventions on lead levels, an additional follow-up sampling effort was conducted in August 2017. Data from this campaign were compared to data from August 2015 and July 2016 to understand city-wide water lead trends at a similar time of year over a three-year period. Overall, 145 Flint residents participated in these three sampling efforts (SI Table S3).

During the August 2017 sampling campaign, WLLs were significantly lower than the prior years $(p<0.05)$, as median WLLs in the first draw steadily dropped from 4.3 to 1.2 to $<1$ $\mu \mathrm{g} / \mathrm{L}$ from 2015 to 2017, and percentage of first draw with reportable lead reduced from $92 \%$ to $54 \%$ to $45 \%$. The 90 th percentile WLL was reduced from 23.5 to 12.1 to $7.9 \mu \mathrm{g} / \mathrm{L}$. Consistent with prior discussions, short-term flushing reduced WLLs, but several homes were still experiencing issues with sporadic spikes in lead. The LCR does not guarantee that a municipality's tap water is free of lead and safe for all residents to consume.?

\section{LEAD IN DRINKING WATER IMPLICATIONS}

Orthophosphate Dosing Can Effectively Inhibit Lead Release from Leaded Plumbing but Its Effectiveness for Particulate Lead Takes Time. Adding orthophosphate inhibitors as a corrosion control treatment strategy can form low-solubility protective passive scale layers, creating a barrier and reducing lead dissolution into water. The effectiveness of this process is controlled by water quality parameters (e.g., $\mathrm{pH}$, alkalinity) and other factors such as disinfectant types, ${ }^{36-38}$ but corrosion control still has some art as well as science, given the complexity of the plumbing systems and poor state of existing knowledge regarding control of particulate lead. ${ }^{39}$ Some U.S. utilities are still experiencing issues with high WLLs even with long-term corrosion control strategies that are considered reasonable. ${ }^{6,7}$

Studies have demonstrated that $1 \mathrm{mg} / \mathrm{L}$ orthophosphate dosing can reduce lead dissolution from older LSLs by more than $70 \%$ for short $(8 \mathrm{~h})$ and long-term $(72 \mathrm{~h})$ stagnation. $^{14}$ However, this intervention may not be as effective in reducing high water lead originating from some brass fittings, as laboratory studies have observed that orthophosphate dosing stabilized brass corrosion but this effect dissipated over time. $^{40,41}$ Orthophosphates might also accelerate galvanic corrosion of lead-solder joints and partial LSL replacements, resulting in increased lead leaching to water from some types of leaded plumbing. ${ }^{42}$ Thus, sole reliance on corrosion control 
strategies like orthophosphate inhibitors, is an important intervention, but will not eliminate occasional spikes of water lead above $15 \mu \mathrm{g} / \mathrm{L}$ at least over a period of years.

The plan to remove lead pipes and lead-bearing galvanized iron service lines will help reduce lead in Flint's drinking water long-term. To date, Lansing, Michigan, and Madison, Wisconsin are the only two cities with high numbers of lead pipes, that have replaced all LSLs in both utility and residentowned sections. ${ }^{43-45}$ These efforts took more than a decade to complete and cost tens of millions of dollars, but Madison considered LSL replacements a more financially effective longterm solution compared to continued corrosion control via phosphate dosing. ${ }^{44}$ However, LSL removals alone will also not guarantee nondetectable lead at the tap, as other leadbearing components and scales within the home plumbing network will then become $100 \%$ of the remaining lead source. $^{34,45}$

The Flint Water Crisis Has Illustrated the Need for Updates to the LCR, Which Includes More Stringent Sampling Protocols. Researchers have identified several weaknesses in the existing $\mathrm{LCR}^{9}$ and investigative reporters have uncovered nation-wide water lead challenges and occasionally improper implementation of the LCR. ${ }^{46-48}$ In 2015, the National Drinking Water Advisory Council recommended that proactive measurements, such as LSL replacement programs and improved public education requirements, are necessary to protect public health, especially since the LCR does not guarantee that tap water is free of lead. ${ }^{49}$ The USEPA accepts that "the regulation and its implementation are in urgent need of an overhaul" ${ }^{\prime 0}$ and is considering a "war on lead". 51 But despite more than 16 years of known problems since the beginning of the Washington DC Lead Crisis, proposed LCR updates are expected no earlier than January 2019. ${ }^{52}$ With these structural flaws in the LCR and its implementation, public health threats will continue to be present in some communities and certainly in individual homes.

One of the key failures that helped create the Flint Water Crisis was use of an improper sampling pool. Per the LCR, sampling priority must be given to high-risk sites, which are outlined in the USEPA's tiered high-risk sampling pool approach. ${ }^{8}$ When LSLs are present in the distribution system, at least $50 \%$ of samples must be from homes with LSLs. However, challenges such as poor record keeping, remodeling of homes, reduced budgets, and lack of trained personnel can result in situations where these conditions cannot be met, so too many samples from nonlead service line pipe sites are sometimes collected when they should not be. ${ }^{53}$ Data from the August 2015 sampling campaign was explored to determine the impact of the percentage of LSLs in the sampling pool (Figure $3)$. The average 90th percentile was $18.2 \mu \mathrm{g} / \mathrm{L}( \pm 5.2 \mu \mathrm{g} / \mathrm{L})$ when $0 \%$ of homes were LSLs $(n=0$ of 30$)$, compared to 31.2 $\mu \mathrm{g} / \mathrm{L}( \pm 8.1 \mu \mathrm{g} / \mathrm{L})$ when $50 \%$ of homes were LSLs, and 68.4 $\mu \mathrm{g} / \mathrm{L}( \pm 10.4 \mu \mathrm{g} / \mathrm{L})$ when $100 \%$ of homes were lead pipe. These results are in keeping with current knowledge that LSLs are the most concentrated source of water lead exposure. ${ }^{54}$ At a minimum, LCR sampling protocols should be revised and updated to ensure stricter enforcement of sampling high-risk homes.

Even in the sampling conducted August 2017, which was after two successive rounds of meeting the LCR according to the official State of Michigan results with a confirmed legal LCR pool, ${ }^{55,56}$ our analysis suggests that viable 90 th percentile

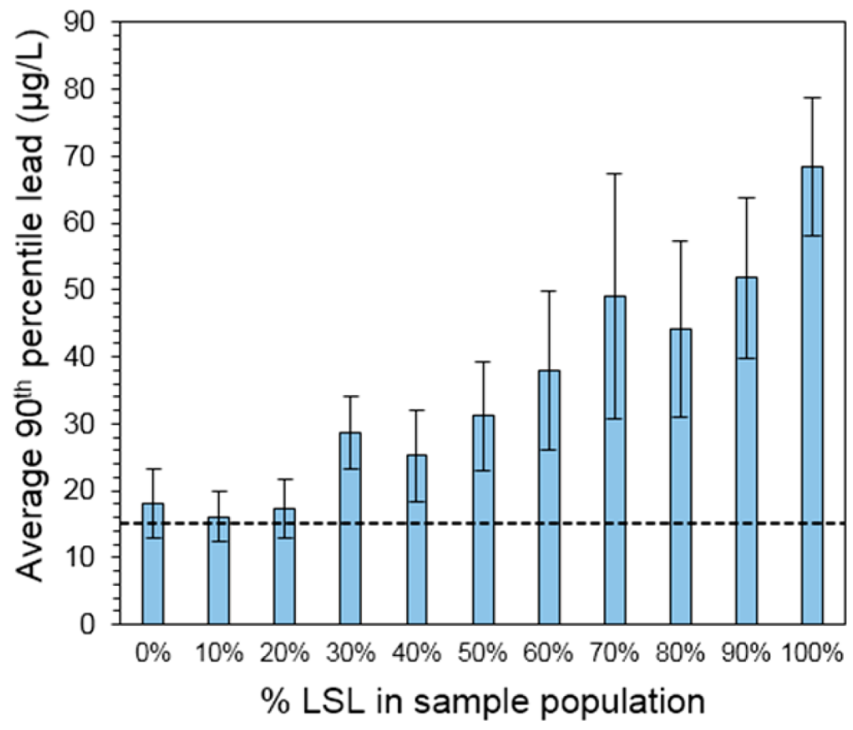

Figure 3. Average 90th percentile lead value in August 2015 when varying the percentage of LSLs included in the sampling population (30 samples per population). Dashed line indicates the action level of $15 \mu \mathrm{g} / \mathrm{L}$. Error bars denote 95\% confidence intervals.

lead value with (50\% LSLs; sampling pool of 44 homes) was $10.7 \mu \mathrm{g} / \mathrm{L}( \pm 1.4 \mu \mathrm{g} / \mathrm{L})$. However, a 100\% LSLs sampling pool (worst-case scenario; sampling pool of 22 homes) had an estimated 90th percentile lead value of $71.5 \mu \mathrm{g} / \mathrm{L}-$ further underscoring the importance of sampling LSLs during LCR monitoring when they are present and the high variability of the $90 \%$ percentile value itself. Overall, our citizen science sampling in August 2017 is no longer inconsistent with the official values reported by the State of Michigan in 2017 (7 and $6 \mu \mathrm{g} / \mathrm{L})$ in relation to the LCR action level.

\section{ASSOCIATED CONTENT}

\section{S Supporting Information}

The Supporting Information is available free of charge on the ACS Publications website at DOI: 10.1021/acs.est.8b00791.

Timeline of citizen science sampling campaigns and state- and federal-level interventions, and water lead levels by sampling campaign, service line materials, and zip codes (PDF)

\section{AUTHOR INFORMATION}

\section{Corresponding Author}

*Phone: 1-540-231-7236; e-mail: edwardsm@vt.edu. ORCID $\odot$

Kelsey J. Pieper: 0000-0002-0273-6527

Min Tang: 0000-0002-4726-1692

\section{Author Contributions}

$\S_{\text {These authors contributed equally to the work }}$

\section{Notes}

The authors declare the following competing financial interest(s): The water crisis remains a contentious issue and is the subject of hundreds of lawsuits. We are not party to any of these lawsuits nor are we expert witnesses for any side in a lawsuit. However, our data and testimony has been subpoenaed. This work was funded by our discretionary funds (Round 1), EPA (Rounds 2, 3, and 4), and crowd sourcing, discretionary funds, and grant from the Greater Flint 
Community Foundation (Round 5). We were openly criticized by state and EPA for our data results in Round 1, and we have been attacked by activists for our data showing improving water quality through 2017.

\section{ACKNOWLEDGMENTS}

This research was supported by discretionary research funding of Dr. Marc Edwards, a National Science Foundation Rapid Research Response grant (\#1556258), a supplement to CBET Award (\#1336650), funding from the Community Foundation of Greater Flint, grants from EPA Region V, and crowdsourced donations. The work of Kelsey Pieper was supported by the Agriculture and Food Research Initiative (\#2016-6701224687) from the U.S. Department of Agriculture National Institute of Food and Agriculture. We acknowledge the 45 person Flint Water Study Team and hundreds of Flint Citizen Scientists for their assistance in executing these sampling programs.

\section{REFERENCES}

(1) Edwards, M.; Dudi, A. Role of chlorine and chloramine in corrosion of lead-bearing plumbing materials. J. - Am. Water Works Assoc. 2004, 96 (10), 69-81.

(2) Schock, M. R.; Giani, R. Oxidant/disinfectant chemistry and impacts on lead corrosion; In the Proceedings of Water Quality and Technology Conference; AWWA: San Antonio, TX, 2004.

(3) Lytle, D.; Schock, M. Formation of $\mathrm{Pb}(\mathrm{IV})$ oxides in chlorinated water. J. - Am. Water Works Assoc. 2005, 97 (11), 102-114.

(4) Edwards, M.; Triantafyllidou, S.; Best, D. Elevated blood lead in young children due to lead-contaminated drinking water: Washington, DC, 2001-2004. Environ. Sci. Technol. 2009, 43 (5), 1618-1623.

(5) Edwards, M. Fetal death and reduced birth rates associated with exposure to lead-contaminated drinking water. Environ. Sci. Technol. 2014, 48 (1), 739-46.

(6) Edwards, M.; Triantafyllidou, S. Chloride-to-sulfate mass ratio and lead leaching to water. J. - Am. Water Works Assoc. 2007, 99 (7), 96-109.

(7) Masters, S.; Edwards, M. Increased lead in water associated with iron corrosion. Environ. Eng. Sci. 2015, 32 (5), 361-369.

(8) U.S. Environmental Protection Agency. Maximum contaminant level goals and national primary drinking $\mathrm{w}$ ater regulations for lead and copper; final rule. Fed. Regist. 1991, 56, 26460.

(9) Katner, A.; Pieper, K. J.; Lambrinidou, Y.; Brown, K.; Hu, C.-Y.; Mielke, H. W.; Edwards, M. A. Weaknesses in federal drinking water regulations and public health policies that impede lead poisoning prevention and environmental justice. Environ. Justice 2016, 9 (4), 109-117.

(10) Schock, M. R. Understanding corrosion control strategies for lead. J. - Am. Water Works Assoc. 1989, 81 (7), 88-100.

(11) Dodrill, D. M.; Edwards, M. Corrosion control on the basis of utility experience. J. - Am. Water Works Assoc. 1995, 87 (7), 74-85.

(12) Vik, E. A.; Ryder, R. A.; Wagner, I.; Ferguson, J. Mitigation of Corrosion Effects. In Internal Corrosion of Water Distribution Systems; AWWA Research Foundation and DVGW Technologiezentrum Wasser, 1996.

(13) McNeill, L. S.; Edwards, M. Phosphate inhibitors and red water in stagnant iron pipes. J. Environ. Eng. 2000, 126 (12), 1096-1102.

(14) Edwards, M.; McNeill, L. Effect of phosphate inhibitors on lead release from pipes. J. - Am. Water Works Assoc. 2002, 94 (1), 79-90.

(15) Wasserstrom, L. W.; Miller, S. A.; Triantafyllidou, S.; Desantis, M. K.; Schock, M. R. Scale formation under blended phosphate treatment for a utility with lead pipes. J. Am. Water Works Assoc. 2017, 109 (11), E464-E478.

(16) Clark, B.; Masters, S.; Edwards, M. Profile sampling to characterize particulate lead risks in potable water. Environ. Sci. Technol. 2014, 48 (12), 6836-6843.
(17) Davis, M.; Kolb, M. C.; Reynolds, L.; Rothstein, E.; Sikkema, K. Flint Water Advisory Task Force: Final Report; State of Michigan Commissioned by the Office of Governor Rick Snyder, 2016; https:// www.michigan.gov/documents/snyder/FWATF_FINAL_REPORT 21March2016_517805_7.pdf (accessed February 6, 2018).

(18) Pieper, K. J.; Tang, M.; Edwards, M. A. Flint Water Crisis caused by interrupted corrosion control: investigating "Ground Zero" home. Environ. Sci. Technol. 2017, 51 (4), 2007-2014.

(19) Del Toral, M. A. High lead levels in Flint, Michigan - interim report. WG-15J; U.S. Environmental Protection Agency Region 5. Chicago, IL, 2015. http://flintwaterstudy.org/wp-content/uploads/ 2015/11/Miguels-Memo.pdf (accessed February 6, 2018).

(20) Edwards, M.; Devine, C. Flint River water is very corrosive to lead, and causing lead contamination in homes. September 2, 2015. http://flintwaterstudy.org/2015/09/flint-rivers-water-is-verycorrosive-to-lead-and-causing-lead-contamination-in-homes/ (accessed February 6, 2018).

(21) Edwards, M. Research update: corrosivity of Flint Water to iron pipes in the city - a costly problem. September 29, 2015. http:// flintwaterstudy.org/2015/09/research-update-corrosivity-of-flintwater-to-iron-pipes-in-the-city-a-costly-problem/ (accessed February 6, 2018).

(22) Hanna-Attisha, M.; LaChance, J.; Sadler, R. C.; Champney Schnepp, A. Elevated blood lead levels in children associated with the Flint Drinking Water Crisis: A spatial analysis of risk and public health response. Am. J. Public Health 2016, 106 (2), 283-290.

(23) Edwards, M. Our sampling of 252 homes demonstrates a high lead in water risk: Flint should be failing to meet the EPA Lead and Copper Rule. FlintWaterStudy: Blacksburg, VA, September 8, 2015. http://flintwaterstudy.org/2015/09/our-sampling-of-252-homesdemonstrates-a-high-lead-in-water-risk-flint-should-be-failing-to-meetthe-epa-lead-and-copper-rule/ (accessed February 6, 2018).

(24) Del Toral, M. A., personal communication, EPA Region 5 Ground Water and Drinking Water Branch, Chicago, IL, 2016.

(25) U.S. Environmental Protection Agency. Flush for Flint. https:// www.epa.gov/sites/production/files/2016-04/documents/flint flush engv8 0.pdf (accessed February 6, 2018).

(26) American Public Health Association. American Water Works Association; Water Environment Federation, Standard methods for examination of water and wastewater; 20th ed.; American Public Health Association, American Water Works Association, \& Water Environment Federation: Washington, D.C., 1998.

(27) Rosencrants, T. Map of Flint's Lead Water Pipes (UPDATED 11/7/16) https://www.umflint.edu/gis (accessed February 6, 2018). (28) Goovaerts, P. The drinking water contamination crisis in Flint: Modeling temporal trends of lead level since returning to Detroit water system. Sci. Total Environ. 2017, 581-582, 66-79.

(29) City of Flint. Annual Water Quality Report. 2014. https://www. cityofflint.com/wp-content/uploads/CCR-2014.pdf (accessed February 6,2018$)$.

(30) Roy, S.; Edwards, M. Chronological compilation of e-mails from MDEQ Freedom of Information Act (FOIA) request 6526-15 and 6525-15. 2015. http://flintwaterstudy.org/wp-content/uploads/ 2015/10/MDEQ-USEPA-Final.pdf.

(31) City of Flint. Annual Water Quality Report. 2015. https://www. cityofflint.com/wp-content/uploads/Flint-CCR-2015-1.pdf (accessed February 6, 2018).

(32) Triantafyllidou, S.; Gallagher, D.; Edwards, M. Assessing risk with increasingly stringent public health goals: the case of water lead and blood lead in children. J. Water Health 2014, 12 (1), 57-68.

(33) Nguyen, C. K.; Stone, K.; Clark, B.; Edwards, M.; Gagnon, G.; Knowles, A. Impact of chloride:sulfate mass ratio (CSMR) changes on lead leaching in potable water. 4088; Water Research Foundation: Denver, CO, 2010.

(34) Clark, B. N.; Masters, S. V.; Edwards, M. A. Lead release to drinking water from galvanized steel pipe coatings. Environ. Eng. Sci. 2015, 32 (8), 713-721. 
(35) Cartier, C.; Bannier, A.; Pirog, M.; Nour, S.; Prevost, M. A rapid method for lead service line detection. J. - Am. Water Works Assoc. 2012, 104 (11), 596-607.

(36) Tam, Y.; Elefsiniotis, P. Corrosion control in water supply systems: Effect of $\mathrm{pH}$, alkalinity, and orthophosphate on lead and copper leaching from brass plumbing. J. Environ. Sci. Health, Part A: Toxic/Hazard. Subst. Environ. Eng. 2009, 44 (12), 1251-60.

(37) McNeill, L.; Edwards, M. Phosphate inhibitor use at US utilities. J. - Am. Water Works Assoc. 2002, 94 (7), 57-63.

(38) Arnold, R.; Edwards, M. Potential reversal and the effects of flow pattern on galvanic corrosion of lead. Environ. Sci. Technol. 2012, 46 (20), 10941-10947.

(39) Edwards, M. A.; Reiber, S. A General Framework for Corrosion Control Based on Utility Experience; 90712A; Water Resarch Foundation: Denver, CO, 1998.

(40) Zhang, Y.; Edwards, M. Effects of $\mathrm{pH}$, chloride, bicarbonate, and phosphate on brass dezincification. J. - Am. Water Works Assoc. 2011, 103 (4), 90-102.

(41) Lytle, D. A.; Schock, M. R. Stagnation time, composition, $p H$ and orthophosphate effects on metal leaching from brass; 600/R-96-103; U.S. Environmental Protection Agency: Washington, D.C., 1996.

(42) Nguyen, C. K.; Clark, B. N.; Stone, K. R.; Edwards, M. A. Acceleration of galvanic lead solder corrosion due to phosphate. Corros. Sci. 2011, 53 (4), 1515-1521.

(43) Gerstein, M. Lansing replaces city's final lead service line. The Detriot News. December 14, 2016. http://www.detroitnews.com/ story/news/local/michigan/2016/12/14/lansing-lead-service-line/ 95435604/ (accessed February 6, 2018).

(44) Schmidt, S. First in the nation: City of Madison replaced all lead pipes. WisconsinWatch.org. February 1, 2016. http://wisconsinwatch. org/2016/02/first-in-the-nation-city-of-madison-replaced-all-leadpipes/ (accessed February 6, 2018).

(45) Schock, M. R.; Cantor, A. F.; Triantafyllidou, S.; Desantis, M. K.; Scheckel, K. G. Importance of pipe deposits to Lead and Copper Rule compliance. J. - Am. Water Works Assoc. 2014, 106 (7), E336E349.

(46) Milman, O.; Glenza, J. At least 33 US cities used water testing "cheats" over lead concerns. The Guardian, June 2, 2016. https://www. theguardian.com/environment/2016/jun/02/lead-water-testingcheats-chicago-boston-philadelphia (accessed February 6, 2018).

(47) Ungar, L. Lead taints drinking water in hundreds of schools, day cares across USA. USAToday. March 3, 2016. https://www.usatoday. $\mathrm{com} /$ story/news/nation/2016/03/17/drinking-water-lead-schoolsday-cares/81220916/ (accessed February 6, 2018).

(48) Ungar, L.; Nichols, M. 4 million Americans could be drinking toxic water and would never know. USAToday. December 13, 2016. https://www.usatoday.com/story/news/2016/12/13/broken-systemmeans-millions-of-rural-americans-exposed-to-poisoned-or-untestedwater/94071732/ (accessed February 6, 2018).

(49) Betanzo, E. Clarifications Needed to Strengthen the Lead and Copper Rule Working Group's Recommendations for Long Term Revisions to the Federal Lead and Copper Rule; 2015. http:// flintwaterstudy.org/wp-content/uploads/2015/11/NEMWI-LCRrecommendations.pdf (accessed February 6, 2018).

(50) U.S. Environmental Protection Agency. Lead and Copper Rule Revisions; White Paper; Washington, DC, 2016. https://www.epa. gov/sites/production/files/2016-10/documents/508_lcr_revisions_ white paper_final 10.26.16.pdf (accessed February 6, 2018).

(51) Siegel, J. EPA's Scott Pruitt declares 'war on lead,' three years after Flint water crisis began. Washington Examiner. January 23, 2018. http://www.washingtonexaminer.com/epas-scott-pruitt-declares-waron-lead-three-years-after-flint-water-crisis-began/article/2646369 (accessed February 6, 2018).

(52) Office of Information and Regulatory Affaris. National Primary Drinking Water Regulations for Lead and Copper: Regulatory Revisions https://www.reginfo.gov/public/do/eAgendaViewRule?pubId= 201704\&RIN=2040-AF15 (accessed February 6, 2018).

(53) Roelofs, T.; Magazine, B. Issues at DEQ cited years before Flint crisis. The Detriot News. February 17, 2016. http://www.detroitnews. com/story/opinion/2016/02/17/issues-deq-cited-years-flint-crisis/ 80532786/ (accessed February 6, 2018).

(54) Edwards, M. Environ. Sci. Technol.; Lecture presented to the US Environmental Protection Agency National Drinking Water Advisory Group, September 18, 2014. https://www.healthandenvironment. org/docs/EdwardsslidesMar82016FIN.pdf (accessed February 6, 2018). 48739

(55) Brown, T. Latest test results show City of Flint's water system at 6 ppb for lead, well below Federal Action Level. Michigan Department of Environmental Quality (MDEQ). August 3, 2017. http://www. michigan.gov/flintwater/0,6092,7-345-76292 $7629476298 \quad 76692$ 76770-427919--,00.html (accessed February 6, 2018).

(56) Brown, T. Flint water quality restored, testing well below Federal Action Level and comparable to other cities across the state. Michigan Department of Environmental Quality (MDEQ). January 12, 2018. http://www.michigan.gov/deq/0,4561,7-135--457586--,00.html (accessed February 6, 2018). 